\title{
CARBON AND OXYGEN ISOTOPE RATIOS IN RONA LIMESTONE, ROMANIA
}

\author{
STELA CUNA ${ }^{1}$, DANA POP ${ }^{2}$, ALEXANDRU HOSU $^{2}$
}

\begin{abstract}
Carbon and Oxygen Isotope Ratios in Rona Limestone, Romania. The carbon and oxygen isotopic compositions of limestones provide criteria for the evaluation of the depositional environment. For Jurassic and younger samples, the best discrimination between marine and fresh-water limestones is given by $Z$ parameter, calculated as a linear correlation between $\delta^{13} \mathrm{C}$ and $\delta^{18} \mathrm{O}$ (\% PDB). Rona Limestone (Upper Paleocene - Lower Eocene), outcropping on a small area in NW Transylvania (Meses area) is a local lacustrine facies. There, it divides Jibou Formation into the Lower Red Member and the Upper Variegated Member, respectively. Recently, a sequence containing a marine nannoplankton assemblage was identified in the base of Rona deposits. The main goal of our study was to characterize, based on the isotopic record, the primary environment of formation of the deposit, as well as that in which some diagenetic processes (the formation of dolomite and of green clay around the siliceous chert nodules) took place. Ten samples representing limestones, dolomitic limestone, marls and the green carbonate-rich clay were studied from petrographical and mineralogical points of view, and the carbon and oxygen isotopic ratios from the carbonate (calcite) component were measured. In conclusion, it was found that the procedure of extraction of $\mathrm{CO}_{2}$ we used enabled the discrimination between the isotopic prints of calcite vs. dolomite. This pleads for considering our results as a primary isotopic pattern in the bulk rock. The oxygen and carbon isotope data indicate a freshwater depositional environment with $Z<120$. The $\delta^{13} \mathrm{C}$ mean value (-4.96 \% PDB) is, generally, representative for fresh-water carbonates of the Tertiary period. The same environment characterized also the formation of carbonates within the green clay.
\end{abstract}

KEY WORDS: mass spectrometry, XRD, carbon and oxygen isotopic compositions, carbonate rocks, paleoenvironment, lacustrine green clay, Rona Limestone, Transylvania, Paleogene

\section{Introduction}

The carbon and oxygen isotopic compositions (the variations of the $\mathrm{C}^{13} / \mathrm{C}^{12}$, and $\mathrm{O}^{18} / \mathrm{O}^{16}$ ratios) of limestones provide criteria for the evaluation of the depositional environment for samples of a wide range of geological age. Especially the carbon isotopes are the most significant, as tracers for

\footnotetext{
${ }^{1}$ National Institute of Research and Development for Isotopic and Molecular Technology, Donath Str., 65-103, POBox 700, RO-400 Cluj-Napoca, Fax: 4064420 042, E-mail: cuna@oc1.itim-cj.ro

2 Babes-Bolyai University, Dept. of Mineralogy, Kogălniceanu Str., 1, RO-3400 Cluj-Napoca, Fax: 4064191 906, E-mail: danapop@bioge.ubbcluj.ro, ahosu@bioge.ubbcluj.ro
} 
the origin of carbon, while oxygen isotopes store paleotemperature information (Clark \& Fritz, 1997).

The isotopic composition of carbon and oxygen is expressed in terms of the $\delta$ (delta) value (given in per mil, \%o), defined as follows:

$$
\delta=\frac{R_{(\text {sample })}-R_{(s \tan \text { dard })}}{R_{(s \tan \text { dard })}} \times 1000
$$

where $R$ represents the isotope ratio: $R=\frac{{ }^{13} \mathrm{C}}{{ }^{12} \mathrm{C}}$ for carbon and $R=\frac{{ }^{18} \mathrm{O}}{{ }^{16} \mathrm{O}}$ for oxygen. If $\delta_{A}>\delta_{B}$, it means that $\mathrm{A}$ is enriched in the rare isotope, or heavier than $\mathrm{B}$.

For various elements, a convenient "working standard" is used in each laboratory. However, in the literature all measured values are compared with an isotopic standard. To convert $\delta$-value from one standard to another, the following equation may be used:

$$
\delta_{X-A}=\left[\left(\frac{\delta_{B-A}}{10^{3}}+1\right)\left(\frac{\delta_{X-B}}{10^{3}}+1\right)-1\right] 10^{3}
$$

where $X$ represents the sample, while $A$ and $B$ various standards. The universally adopted standard for carbon and oxygen stable isotope variation in carbonates was the so-called $\mathrm{PDB}^{3}$, while in natural waters was the so-called SMOW ${ }^{4}$.

The main mineral components of carbonate rocks are calcite and dolomite. Dolomite typically shows higher $\delta^{13} \mathrm{C}$ and $\delta^{18} \mathrm{O}$ values as compared to calcite, due to the enrichment in ${ }^{13} \mathrm{C}$ and ${ }^{18} \mathrm{O}$ occuring during dolomitecalcite fractionation. In addition, diagenetic processes lead to a relative enrichment in ${ }^{13} \mathrm{C}$ in both minerals (Clark \& Fritz, 1997).

The $\delta^{13} \mathrm{C}$ (PDB) values for marine carbonate rocks are usually constant and close to 0 . On the other hand, the fresh-water limestones are usually enriched in ${ }^{12} \mathrm{C}$ as a result of the organic influences (plant respiration, oxidation of organic rests etc.), and the $\delta^{13} \mathrm{C}$ (PDB) values are more scattered (Faure, 1977).

In the references, the oxygen isotopic ratio for carbonates was compared to both PDB and SMOW. The $\delta^{18} \mathrm{O}$ values in the case of freshwater carbonate rocks are usually lower, due to a depletion in ${ }^{18} \mathrm{O}$ as compared to sea waters (Faure, 1977) and may vary within larger limits (Table 1).

Table 1

\footnotetext{
${ }^{3} \mathrm{PDB}$ originates from the $\mathrm{CaCO}_{3}$ of the rostrum of a Cretaceous belemnite (Belemnitella americana) collected in the Peedee Formation of South Carolina, USA. It has absolute ratios ${ }^{13} \mathrm{C} /{ }^{12} \mathrm{C}=11237.2 \pm 2.9$ and ${ }^{18} \mathrm{O} /{ }^{16} \mathrm{O}=2067.1 \pm 2.1$

${ }^{4} \mathrm{SMOW}$ (Standard Mean Ocean Water) corresponds to a hypothetical water sample having both oxygen and hydrogen isotopic ratios equal to the mean isotopic ratios of ocean water, which have been evaluated as ${ }^{18} \mathrm{O} /{ }^{16} \mathrm{O}=(1993.4 \pm 2.5) \times 10^{-6}$ and $\mathrm{D} / \mathrm{H}=(158 \pm 2) \times 10^{-6}$ 140
} 
Carbon and oxygen isotope ratios in carbonate rocks, according to previous references

\begin{tabular}{|c|c|c|}
\hline Reference & Marine & Fresh-water \\
\hline \multicolumn{3}{|c|}{$\delta^{13} \mathrm{C}(\%$ PDB $)$} \\
\hline 1 & mean value: +0.56 & mean value: -4.93 \\
\hline 2 & $\begin{array}{l}\text { shallow deposits: }(+2-+4.5) \\
\text { deep sea deposits: }(0-+2)\end{array}$ & $\begin{array}{l}\text { limits of variation: } \\
(-17--2)\end{array}$ \\
\hline 3 & $\begin{array}{l}\text { mean values: }(+0.56-+1.55) \\
\text { limits of variation: }(-0.99-+2.11)\end{array}$ & $\begin{array}{l}\text { limits of variation: } \\
(-7.68-2.18)\end{array}$ \\
\hline \multicolumn{3}{|c|}{$\delta^{18} \mathrm{O}(\% \mathrm{PDB})$} \\
\hline 1 & mean value: -5.25 & mean value: -8.66 \\
\hline 2 & $\begin{array}{l}\text { shallow deposits }(-0.5-+1.5) \\
\text { deep sea deposits }(+1-+3)\end{array}$ & $\begin{array}{l}\text { limits of variation: } \\
(-10-+4)\end{array}$ \\
\hline
\end{tabular}

References: 1 - Keith \& Weber (1964) (selected group of samples)

2 - Veizer (1983), according to the diagram of Milliman (1974)

3 - Faure (1977)

For Jurassic and younger samples (assumed to be nonrecrystallized rocks) the best discrimination between marine and freshwater limestones is given by the following equation (Keith \& Weber, 1964):

$$
Z=2.048\left(\delta^{13} \mathrm{C}+50\right)+0.498\left(\delta^{18} \mathrm{O}+50\right)
$$

where both $\delta^{13} \mathrm{C}$ and $\delta^{18} \mathrm{O}$ are expressed as \% PDB. Limestone samples with a $Z$ value above 120 would be classified as marine, while those with $Z$ below 120 as fresh-water ones. Geologically older specimens can probably be better classified into marine and fresh-water categories using the carbon isotope ratio alone.

\section{Geological background}

Rona Limestone is a lens-shaped body located in NW Transylvania, having a local development. The classic outcrop is located westwards from Jibou (Sălaj district), on the right bank of Someş river, near Rona village. In the neighborhoods of Jibou and Rona the deposit has the maximum thickness of about $300 \mathrm{~m}$; towards NE it gradually becomes thinner, until it disappears in the area of Caselor and Gard Brooks (Popescu, 1984). 


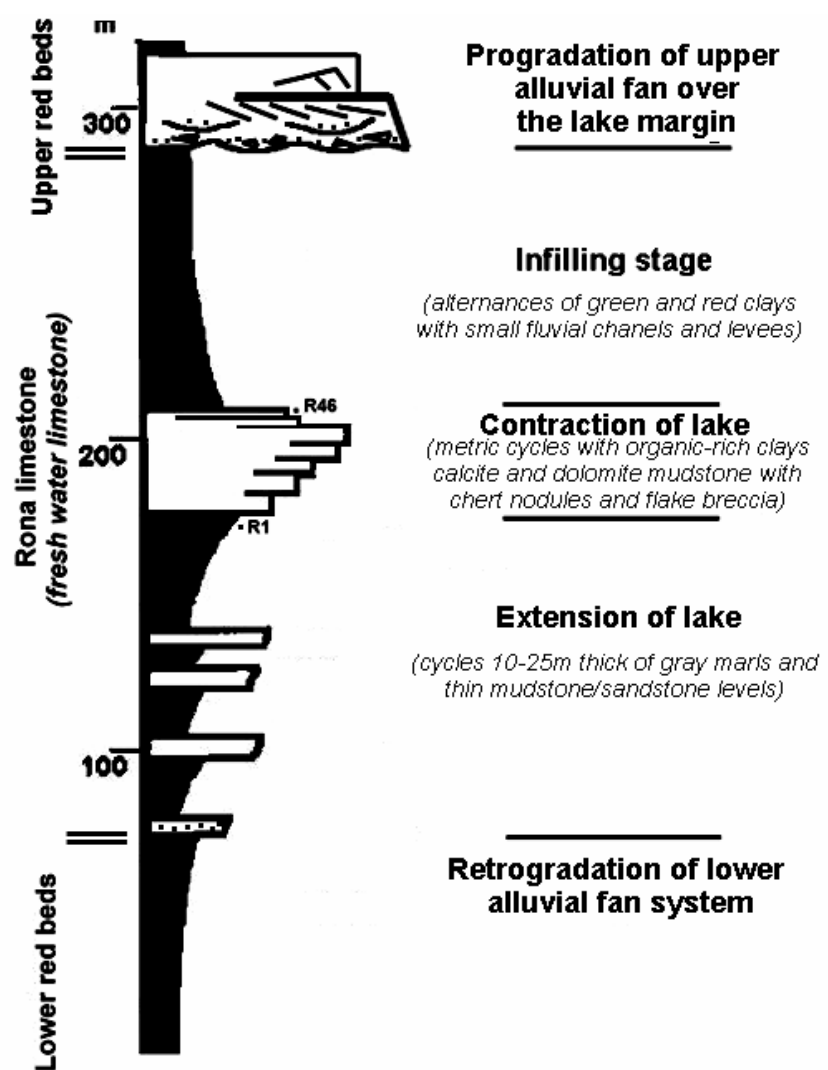

Fig. 1. - Synthetic sedimentological log of Jibou Formation in Rona area and location of samples under study (R1-R46)

Rona Limestone outcrops only in Meseş area - which is the median sector of deposition of Paleogene formations in the NWrn part of the Transylvanian Depression. Stratigraphically, it divides Jibou Formation into the Lower Red Member and the Upper Variegated Member, respectively (Popescu, 1984).

The deposits consist of limestone with organic content interlayered with dolomite beds, and grayish-greenish mudstones or clayey sands (Popescu, 1984). Due to the content of mollusk lumaschelles (limneids and planorbis), ostracods and Chara algae, the deposit was being described for a long time as fresh-water limestone (Hauer \& Stache, 1863; Koch, 1894). It was considered to be one of the thickest formation of this type in the European Eocene (Popescu, 1984). The age of Rona Limestone is Late Paleocene - Early Eocene (Gheerbrant et al., 1999). Even if the lacustrinepalustrine environment of formation is now widely accepted, there were 142 
other opinions, as well: Szádeczky (1915, in Paucă, 1977) considered Rona Limestone as a desert-type formation; Paucă (1977) named it "the most extended continental evaporite from Romania".

More recently (Mészaros, 1995), deposits containing a marine nannoplankton assemblage belonging to the NP 14 zone (Middle Lutetian) were identified "below the green illite level", but within "the green illite nests" in the base of Rona lacustrine deposits. There is no detailed location along Rona profile given for this marine level and some uncertainty still persists. In conclusion, the author includes a thick (more than $80 \mathrm{~m}$ ) marine (littoral) sequence between the Lower Jibou Formation and the Rona Beds, which he makes responsible for the formation of the hydrocarbon deposits from Bârsa.

From mineralogical and genetic points of view, the presence of chert nodules surrounded by green clay of a diagenetic nature - as a unique paragenesis in the Romanian references - is particularly worthy to mention. In the lower part of the succession, at about $10 \mathrm{~m}$ from the base of the classic Rona profile, these chert nodules ("septaria") of spherical to ellipsoidal morphologies are hosted by a $30-40 \mathrm{~cm}$ thick level of carbonate rock (Ghiurcă \& Tudoran, 1997). The chert nodules are of gemological interest (Ghiurcă \& Pop, 1994; Ghiurcă, 2000). They are always surrounded by an intensely colored green clay coating, $0.5-1 \mathrm{~cm}$ thick (mentioned as nests of green marls by Bombiță \& Baltreş, 1986).

The above relatively extended geological information was meant to explain the premises and our reasons for undertaking the study of the carbon and oxygen isotopic composition:

1. to check, by isotopic geochemistry means, if a certain environmental print can be noticed;

2. to clarify if there is any marine influence in the samples under study, as suggested by Mészaros (1995); and

3. to define the environment of formation of the green clay and of the hostrock at the level of the chert nodules.

\section{Samples and analytical methods}

Ten samples, among which nine of carbonate rocks and one (R28V) of the green clay surrounding the chert nodules were collected from the classic outcrop near Rona village. Sample R28 represents the carbonate rock that hosts the chert nodules. The location of the studied samples along Jibou Formation profile is presented in Fig. 1. The samples were mineralogically and petrographically analyzed, by means of optical microscopy on thin sections, and X-ray diffraction. Sedimentological observations were recorded in the field, as well as under microscope. The 
X-ray study was carried out using the DRON-3 diffractometer ${ }^{5}$ with $\mathrm{Cu}$ anticathode, on both powder mounts and on oriented samples (air-dried and glycolated).

For carbon and oxygen isotope measurements, samples were crushed to $100 \mu \mathrm{m}$ mesh size and heated at $400{ }^{\circ} \mathrm{C}$ for about 30 minutes in order to drive off volatile organic compounds. The $\mathrm{CO}_{2}$ for mass spectrometer analysis was obtained from the reaction of carbonate with $100 \%$ phosphoric acid, at $25^{\circ} \mathrm{C}$ (Mc Crea, 1950). The gas was collected, purified and analyzed in the ATLAS 86 mass spectrometer with double collector ${ }^{6}$. Our "working standard" was Carrara marble, with $\delta^{13} C=+1.96 \%$ and $\delta^{18} \mathrm{O}=-1.96 \%$. Measured data were corrected using Craig's formula (Craig, 1957). The random analytical error is less than $0.1 \%$. Recorded $\delta$ values are the mean values of replicate runs.

Due to the presence in the analyzed samples of both calcite and dolomite in various ratios, some details on the analytical procedure are worthy to mention. The methods of investigation and calculation of the isotopic ratios are the same for both minerals, but the procedure of extraction of $\mathrm{CO}_{2}$ is slightly different. The $\mathrm{CO}_{2}$ released during the first hour of reaction has essentially the same $\delta$ values as that from pure calcite; as the reaction follows, $\mathrm{CO}_{2}$ collected between 4 to $72 \mathrm{~h}$ has the same $\delta$ values as that from pure dolomite (Degens \& Epstein, 1964). In our investigation, the acidic attack was performed for $1 \mathrm{~h}$, in order to prevent the contribution of the carbon and oxygen isotopes from dolomite in the resulting $\mathrm{CO}_{2}$. Thus, we considered that the isotopic compositions were indicative only for the syngenetic processes, which lead to the formation of calcite, and were probably not influenced by the diagenetic environment that transformed part of the calcite into dolomite.

\section{Results}

According to the petrographical and sedimentological features, the carbonate facies are stacked like transgressive-regressive cycles, two main lithofacies associations being recognizable in a sequence (Hosu \& Pop, 1995):

1. Lacustrine association with lime mudstone to packstone with scarce mollusks and charophyte debris, interbedded with black-greenish shales sometimes organic-rich. The lack of bioturbations at some levels indicates the presence of water stratification and anoxia.

\footnotetext{
${ }^{5}$ at the Department of Mineralogy, Babes-Bolyai University in Cluj-Napoca

${ }^{6}$ at the National Institute of Research and Development for Isotopic and Molecular Technology, Cluj-Napoca 144
} 
2. Palustrine association with pellet and intraclast grainstones or packstones, the intraclasts representing reworked fragments of brecciated sediments exposed at the lake margins. Pedogenetically modified limestones are characterized by the development of calcareous soils, exhibiting features as brecciation, root tubules, microkarst, various cavities or iron oxide mottling.

The processes of dolomitization that were noticed in several carbonate sequences plead for an advanced degree of diagenesis.

The diffractograms of the nine carbonate-rich samples indicate the dominance (60-90 \%) of calcite and dolomite in various ratios, besides which clay minerals (5-30 \%) and quartz (<5\%) are also present (Table 2). Thus, the nine samples can be defined as limestones (R20, R25, R28, R35), dolomitic limestone (R6) and marls (R1, R16, R32, R46).

Table 2

Relative participation of the main mineralogical components in the analyzed samples (semi-quantitative)

\begin{tabular}{cccccc}
\hline Sample & \multicolumn{2}{c}{$\begin{array}{c}\text { CARBONATES } \\
\text { (relative frequency, } \% \\
\text { among carbonate minerals) } \\
\text { Calcite }\end{array}$} & $\begin{array}{c}\text { NON-CARBONATE MINERALS } \\
\text { Dolomite }\end{array}$ & $\begin{array}{c}\text { Q } \\
\text { Quartz } \\
\text { of each component) } \\
\text { Smectite }\end{array}$ & Illite \\
\hline R1 & 55 & 45 & $*$ & $*$ & $*$ \\
R6 & 30 & 70 & $*$ & $*$ & $*$ \\
R16 & 65 & 35 & $*$ & $*$ & $*$ \\
R20 & 70 & 30 & $*$ & $*$ & $*$ \\
R25 & 70 & 30 & $*$ & $*$ & $*$ \\
R28 & 95 & 5 & $*$ & $*$ & $*$ \\
R28V & 85 & 15 & $*$ & $*$ & $*$ \\
R32 & 95 & 5 & $*$ & $*$ & $*$ \\
R35 & 95 & 5 & $*$ & $*$ & $*$ \\
R46 & 80 & 20 & & & $*$ \\
\hline
\end{tabular}

The clay minerals assemblage is dominated by smectite, which is present in all the analyzed samples. Besides it, illitic material is present in some carbonate levels, in both the calcite-rich (R20, R25, R32, and R35) and the dolomite-rich (R6) ones. Some 10-14M interstratifications having variable degrees of ordering can also be mentioned, being subordinated in the mixture. As referred to a sequence, the amount of illite-type material increases upwards, while the smectites decline. Thus the maximum illite participation is located in the palustrine association, suggesting a pedogenic illitization process.

Sample R28V represents a carbonate-rich clay (30\% carbonate minerals, very poorly crystallized) with a relatively high content of quartz $(10 \%)$. The clay assemblage is clearly dominated by the illite-type phase, besides which smectite is also present. Some previous investigations (Pop 
et al., 1995) based on Mössbauer spectroscopy and XRF showed that the green clay has a relatively high amount of $\mathrm{Fe}$. Due to the lack of chemical data, the mineralogical nature of the illitic phase was not clearly defined: the authors were assuming either "Fe-illite" or a "glauconitic mineral". As a preliminary result, it was found that the $10 \AA$ phase from the green crusts is diffractometrically very similar with the illitic material present along the sampled profile. Table 3 .

The carbon and oxygen isotope data are reported as $\delta$ (\% PDB) in

Carbon and oxygen isotope ratios and calculated $Z$ parameter

\begin{tabular}{cccl}
\hline Sample & $\delta^{13} \mathrm{C}(\%$ PDB $)$ & $\delta^{18} \mathrm{O}(\%$ PDB) & $\mathrm{Z}$ \\
\hline R1 & -4.02 & -14.13 & 112.03 \\
R6 & -5.11 & -13.72 & 110.00 \\
R16 & -4.15 & -14.78 & 111.44 \\
R20 & -5.40 & -11.33 & 110.60 \\
R25 & -6.07 & -13.39 & 108.20 \\
R28 & -4.91 & -15.68 & 109.44 \\
R28V & -6.78 & -14.60 & 106.14 \\
R32 & -5.49 & -8.62 & 111.76 \\
R35 & -4.56 & -19.20 & 108.40 \\
R46 & -3.12 & -9.41 & 116.22 \\
\hline
\end{tabular}

\section{Discussion}

Lacustrine calcite records the stable isotope fractionation patterns of several overlapping genetic processes involving bedrock geology, vegetation of the lake and its surroundings, soil formation, hydrogeology and possibly, environmental change (Hammarlund et al., 1997). Besides, diagenetic factors should be added. Without comparative data on carbon and oxygen isotopic compositions and carbon distribution in several types of materials, such as mollusk shells, ostracode valves and possibly relic Chara encrustations, a refined analysis is difficult to be done, and beyond our purpose. Based on the current results, some aspects are still relevant for the general environment of formation of Rona Limestone.

The first topic under discussion is whether the isotopic compositions reflect only the environment of deposition of the carbonates from Rona, or if diagenesis also influenced the carbon and oxygen ratios? In principle, the discussion should be reduced to the different isotopic contributions which calcite vs. dolomite can bring to the final $\delta^{13} \mathrm{C}$ and $\delta^{18} \mathrm{O}$ values. Our cautions were firstly taken concerning the extraction procedure, as already mentioned. More, having a closer look at the various samples and their isotopic data, supplementary control can be obtained. Thus, R6 contains the highest 
amount of dolomite among the studied samples, while R28, R32 and R35 show the highest amounts of calcite (samples R32 and R28 have also significant amounts of clay minerals). In spite of this fact, both the $\delta^{13} \mathrm{C}$ and $\delta^{18} \mathrm{O}$ values for $\mathrm{R} 6$ fall within the limits of variation of the other three samples. Based on these arguments, we believe it is realistic to assume that dolomite - thus diagenesis, did not significantly overprint the carbon and oxygen isotope measured values.

Concerning the carbon isotopes, the $\delta^{13} \mathrm{C}(\mathrm{PDB})$ values are typical for fresh-water carbonates (they range between $-3.12--6.78 \%$ ), all being below $-3 \%$ (Table 3 ). These values are consistent with the isotopic record $(-4 \% \pm 1 \%$ ) on the organic-rich units of a Holocene lacustrine carbonate sequence (Hammarlund et al., 1997). Along the profile, some trends can be noticed:

- in the lower part there is a systematic variation of the $\delta^{13} \mathrm{C}$ (PDB) values; theoretically this means a relatively enrichment in ${ }^{13} \mathrm{C}$ in samples $\mathrm{R} 1, \mathrm{R} 16$, and enrichment in ${ }^{12} \mathrm{C}$ (of an organic origin) in samples R6, $\mathrm{R} 20$, and R25. The differences are relatively small, but they are above the random analytical error. The geological meaning of this fact could be related to rhythmical changes between lacustrine and palustrine environments.

- in the upper part of the analyzed profile an increasing trend of the $\delta^{13} \mathrm{C}$ values is noticeable from samples R32 to R46. This is due to a gradual enrichment in ${ }^{13} \mathrm{C}$, which could be explained by progressive restriction of palustrine environments.

- when comparing samples R28 (carbonate host-rock) with R28V (green clay), quite different carbon isotopic ratios can be noticed. In fact, sample $\mathrm{R} 28 \mathrm{~V}$ registers the lowest $\delta^{13} \mathrm{C}$ value $(-6.78 \%)$ in the samples under study, while sample R28 shows a value $(-4.91 \%)$ close to the average one for the carbonate succession along the profile.

This fact could be the result of various causes, among which:

- the different mineralogical nature of the samples (R28V is a clay-dominated sample, whilst R28 is calcite-rich) might have lead to different isotopic fractionation patterns;

- the different environmental conditions of formation - a primary genesis is assumed for the host-rock while the green clay probably formed during diagenesis.

The relative ${ }^{13} \mathrm{C}$-enrichment of some biogenic calcite-rich levels (leading to relatively higher $\delta^{13} \mathrm{C}$ values) may be correlated with the carbon isotope separation pattern of Chara algae, which were previously identified in Rona Limestone. Hammarlund et al. (1997) proposed a kinetic carbon isotope fractionation model of photosynthetic assimilation of dissolved 
inorganic carbon by means of proton pumping that can explain some of the variations of the $\delta^{13} \mathrm{C}$ values.

For oxygen isotopes, the limits of variation of the $\delta^{18} \mathrm{O}(\mathrm{PDB})$ values range between $(-8.62--19.20) \%$ (Table 3$)$. A somehow reversed trend as compared to the $\delta^{13} \mathrm{C}$ values - can be noticed in the lower part of the profile. No clear trend is obvious in the upper part. When comparing the values of samples R28V vs. R28, a slight enrichment in ${ }^{18} \mathrm{O}$ can be noticed in the calcite from the green clay, as compared to the carbonate host-rock.

An interesting feature is worthy to mention when comparing our data with previous results in the literature, plotted in Fig. 2. In general, there is a clear separation between the fresh-water limestones and the marine (both shallow-water and deep-sea) ones. The samples from Rona plot in a distinctive field, which partly overlaps the fresh-water limestones.

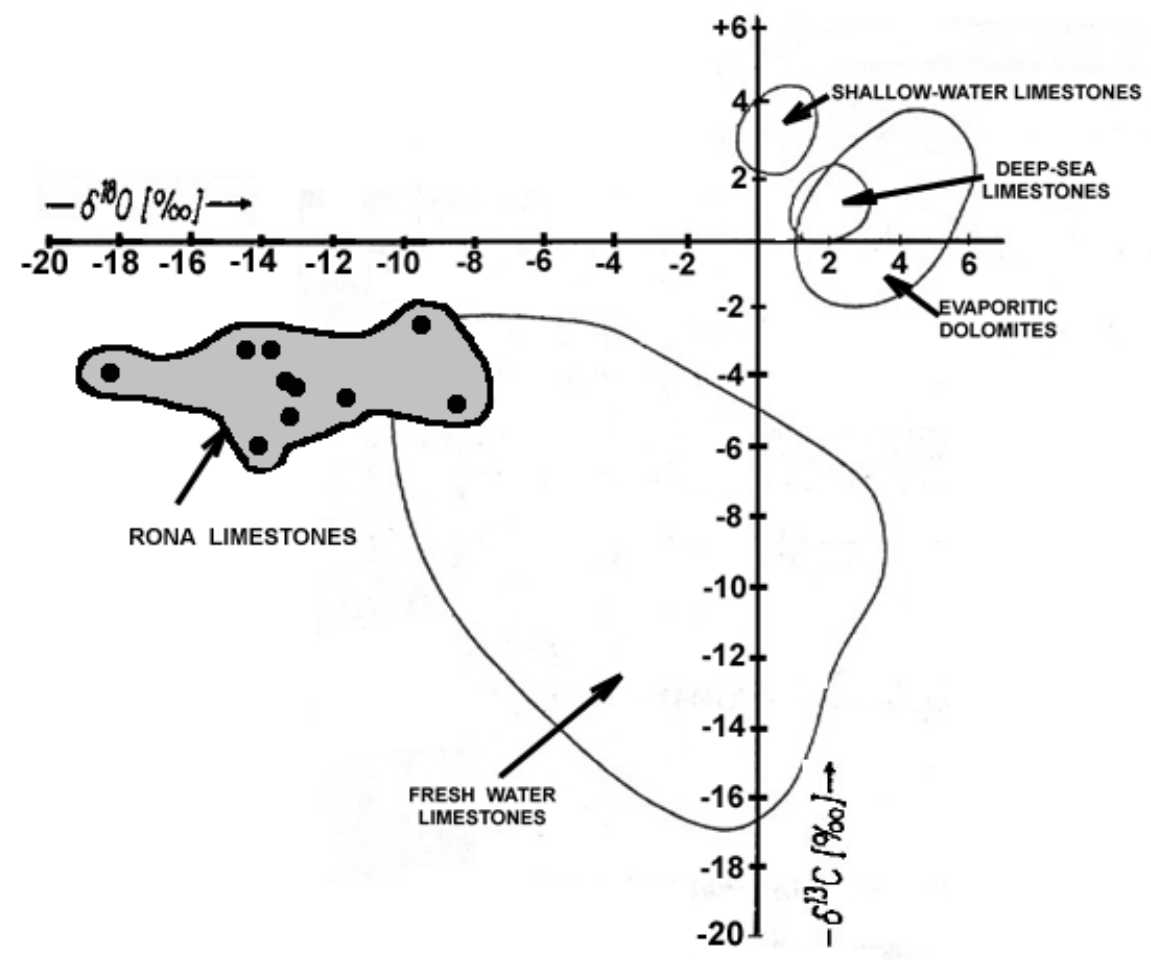

Fig. 2. - Distribution of $\delta^{18} \mathrm{O}$ vs. $\delta^{13} \mathrm{C}$ (\% PDB) values in various types of carbonate rocks, including this study (after Milliman, 1974, in Veizer, 1983) 
At the same time, the relatively low $\delta^{18} \mathrm{O}(\mathrm{PDB})$ ratios $(<-10 \%)$ are unusual when compared with other data in the references. These values suggest a ${ }^{18} \mathrm{O}$ depletion in most of our samples (excepting R32, and R46). A relationship between the mineralogical composition and the $\delta^{18} O$ values could not be identified. The cause of this fractionation pattern cannot be evidenced starting from the current data. As working hypotheses, the influence of climaterelated changes, and/or changes in the terrestrial vegetation of the lake catchment could be used, as suggested by Hammarlund \& Edwards (1998) in the case of Holocene lacustrine carbonates. Their samples of fine-grained calcite showed values up to $13.5 \%$. The synthetic $Z$ parameter based on both $\delta^{13} \mathrm{C}$ and $\delta^{18} \mathrm{O}$ shows values characterizing the fresh-water carbonates (between 106.14 - 116.22) for all the analyzed samples (Table 3).

Concerning the mineralogical nature of the green clay around the chert nodules, our study does not bring new results. Due to the $\delta^{13} \mathrm{C}$ value which is representative for the fresh-water environments, one can only presume that the green clay is more likely to be a Fe-illite than a glauconitic mineral - the latter one being typically of marine origin. But even in nonmarine conditions, a large mineralogical variety of green clays can be formed, including glauconite (Porrenga, 1968). Anyhow, the genetic criterion is not valid when defining the mineral species, according to AIPEA classification (Bailey, 1980); only crystal chemistry should be taken into consideration. For that, more detailed analytical data are needed.

\section{Conclusions}

1. The procedure of extraction of $\mathrm{CO}_{2}$ we used enabled the discrimination between the carbon and oxygen isotopic patterns of calcite vs. dolomite; in our case, the primary environment of formation could thus be recorded without the diagenetic overprint.

2. The oxygen and carbon data on samples from Rona Limestone indicate a fresh-water depositional environment, with $Z<120$. The mean carbon isotopic composition (-4.96\%) fits the values for fresh-water carbonates of the Tertiary period, in general.

3. The $\delta^{13} \mathrm{C}$ and $\delta^{18} \mathrm{O}$ values obtained for the carbonate minerals in the green clay surrounding the chert nodules also suggest a fresh-water carbonate paleoenvironment.

\section{Acknowledgement}

The authors wish to thank the reviewers (B. Onac, C. Ionescu, and L. Ghergari) for some of their critical comments, which helped to improve the manuscript. 


\section{REFERENCES}

1. Bailey S. W. (1980). Summary of recommendations of AIPEA Nomenclature Committee. Clays and Clay Minerals. 28, 1, 73-79.

2. Bombiță G., Baltreş N. (1986). Contributions á l'étude des calcaires lacustres éocènes de Transylvanie. D. S. Inst. Geol. Geofiz., 70-71, 4, 227-244.

3. Clark I. D., Fritz P. (1997). Environmental Isotopes in Hydrogeology. Lewis Publishers, New York, 328 p.

4. Craig H. (1957). Isotopic standards for carbon and oxygen and correction factors for mass spectrometric analysis of carbon dioxide. Geochim. Cosm. Acta, 12, 133-149.

5. Degens E.T., Epstein S. (1964). Oxygen and carbon isotope ratios in coexisting calcites and dolomites from recent and ancient sediments, Geochim. Cosm. Acta, 28, 23-44.

6. Faure G. (1977). Principles of Isotope Geology, Ed. John Wiley \& Sons, Inc., New York, 384-386.

7. Gheerbrant E., Codrea V., Hosu A., Sen S., Guernet C., Lapparent de Broin F. \& Riveline, Janine (1999). Découverte de vertébré dans les Calcaires de Rona (Thanétien ou Sparnacien), Transylvanie, Roumanie: les plus anciens mammiferes cénozoiques d'Europe Orientale. Eclogae geol. Helv., 92, 517-535.

8. Ghiurcă V. (2000). Septaria silicieux de Roumanie. Minéraux \& Fossiles, 289, 25 30.

9. Ghiurcă V., Pop Dana (1995). Typical Gemologic Raw Materials from Romania. In: Abstracts Volume of the Precious Stones and Metals, 3rd biannual meeting "Intergems", Turnov, Czech Republic, 42-50.

10. Ghiurcă V., Tudoran V. (1997). Septariile silicioase din calcarele de Rona. Studii şi Cercetări (Şt. Naturii), 3, 73-79, Muzeul Județean Bistrița, Ed. Carpatica, Cluj-Napoca.

11. Hammarlund D., Aravena R., Barnekow Lena, Buchardt B., Possnert G. (1997). Multi-component carbon isotope evidence of early Holocene environmental change and carbon-flow pathways from a hard-water lake in northern Sweden. Journal of Paleolimnology, 18, 219-233.

12. Hammarlund D., Edwards T. W. D. (1998). Evidence of changes in moisture transport efficiency across the Scandes mountains in northern Sweden during the Holocene, inferred from oxygen isotope records of lacustrine carbonates. Isotope Techniques in the study of environmental change. Proceedings of an international symposium on isotope techniques in the study of past and current environmental changes in the hydrosphere and the atmosphere. International Atomic Energy Agency, Vienna, 573-580.

13. Hauer F. R. V., Stache G. (1863). Geologie Siebenbürgens. Ed. W. Braumüller, Wien, $636 \mathrm{p}$.

14. Hosu A., Pop Dana (1995). Some mineralogical features of lacustrine deposits. Examples from Rona limestone, Sălaj district. Rom. J. Mineralogy, 77, Suppl. 1, p. 21. 
15. Keith M. L., Weber Y. N. (1964). Carbon and oxygen isotopic composition of selected limestone and fossils. Geochem. Cosm. Acta, 28, 1787-1816.

16. Koch A. (1894). Die Tertiärbildunges der Beckens der Siebenbürgischen Landestheile. I. Paläeogene Abteilung. Mitt. Aus d. Jb. Kgl. Ung. Geol. Anst., X, 6, 179-397, Budapest.

17. Mc Crea J. M. (1950). On isotopic chemistry of carbonates and a paleotemperature scale. J. Chem. Phys., 18, 849-857.

18. Mészaros N. (1995). Marine deposits in the continental deposits of the Jibou Formation. Studii şi Cercetări, 1, 59-61. Muzeul Județean Bistrița, Ed. Carpatica, Cluj-Napoca.

19. Paucă M. (1977). Le calcaire de Rona - genèse et répartition. Trav. Mus. Hist. Nat. "Gr. Antipa", XVIII, 341-347, Bucureşti.

20. Pop Dana, Hosu A., Dărăban, L., Constantinescu, Ş. (1995). Mineralogical characterization of the green clay from the Rona limestone. Rom. J. Mineralogy, 77, Suppl. 1, p. 36.

21. Popescu B. M. (1984). Lithostratigraphy of cyclic continental to marine Eocene deposits in NW Transylvania, Romania. Arch. Sci. Genève, 37, 1, 37-73.

22. Porrenga D. H. (1968). Non-marine glauconitic illite in the Lower Oligocene of Aardebrug, Belgium. Clay Minerals, 7, 421-430.

23. Veizer J. (1983). Trace Elements and Isotopes in Sedimentary Carbonates. In R. J. Reeder (Ed.): Carbonates: Mineralogy and Chemistry, Reviews in Mineralogy, 11, 278-279. 